\title{
Assay of Insulin-like Activity by the Isolated Fat Cell Method*
}

\author{
III. Studies on the non-suppressible insulin-like activity of serum.
}

\author{
Jørgen GLIEmanN
}

Institute of Medical Physiology A, Juliane Mariesvej 28, Copenhagen $\emptyset$, Denmark

Received June 26, 1967

\begin{abstract}
Summary. Human sera prepared in different ways were assayed for insulin-like activity (ILA) by the isolated fat cell method, with and without insulin antibodies. The lowest values of non-suppressible ILA (equivalent to $20-40 \mu \mathrm{U}$ of insulin per ml) were found when sera were prepared in an atmosphere of $5 \% \mathrm{CO}_{2}$. The non-suppressible ILA increased when sera were prepared with air as the gas phase or when heparin was added to the blood samples, whereas the suppressible ILA remained unchanged. Haemoglobin (0.1 mg per $\mathrm{ml}$ or more) depressed the activity of suppressible IL $A$ but not of non-suppres. sible ILA. The non-suppressible ILA of rat serum varied with the nutritional state of the animals. It declined during fasting and when the animals were given a high fat diet. The activity of crystalline insulin and of nonsuppressible ILA was quantitatively recovered when added to sera from fasted or fat-fed rats. - A variety of different treatments of serum increased the ILA. Acidalcohol extraction, incubation with heparin, "warm dialysis", and electrophoretic fractionation caused a rise of the non-suppressible ILA but not of the suppressible ILA. - The results indicated that non-suppressible ILA is present in native serum and is likely to be physiologically significant. The concept of a form of insulin in serum different from suppressible ILA was not supported.
\end{abstract}

Dosage de l'activité insulinique par la méthode des cellules adipeuses isolées. III. Etudes sur l'activité insulinique non-supprimable du sérum

Résumé. L'activité insulinique (ILA) de sérums humains préparés de différentes manières a été dosée par la méthode de la cellule adipeuse isolée avec et sans anticorps anti-insuline. Les valeurs les plus basses de l'ILA non-supprimable (équivalent à $20-40 \mu \mathrm{U}$ d'insuline par $\mathrm{ml}$ ) ont été trouvées quand les sérums avaient été préparés dans une atmosphère contenant $5 \%$ de $\mathrm{CO}_{2}$. L'ILA non-supprimable augmentait quand les sérums étaient préparés avec de l'air comme phase gazeuse ou quand on ajoutait de l'héparine aux échantillons de sang, tandis que 1'ILA supprimable demeurait inchangée. L'hémoglobine (0.1 mg par $\mathrm{ml}$ ou plus) diminuait l'activité do I'ILA supprimable mais non celle de l'ILA non-supprimable. L'ILA non-supprimable du sérum de rat variait suivant l'état nutritionnel des animaux. Elle diminuait pendant le jeûne et quand les animaux étaient soumis à un régime riche en matières grasses. L'activité de l'insuline cristalline et de l'TLA non-supprimable était retrouvée quantitativement quand on l'ajoutait à des sérums de rats à jeun ou nourris avec des matières grasses. - Plusieurs traitement différents du sérum augmentaient l'II.A. L'extraction à l'acide-alcool, l'incubation avec de l'héparine, "la dialyse à chaud " et le fractionnement électrophorétique provoquaient une augmentation de l'ILA nonsupprimable mais pas de l'TLA supprimable. - Les résultats indiquaient que I'ILA non-supprimable est présente dans le sérum naturel et a probablement une signification physiologique. La conception selon laquelle il existe dans le sérum une forme d'insuline différente de l'ILA supprimable, n'a pas été confirmée.

Bestimmung der insulinähnlichen Aktivität (ILA) mit der Methode isolierter Fettzellen. III. Studien über die nichthemmbare insulinähnliche Aktivität des Serums.

Zusammenfassung. Mit der Methode isolierter Fettzellen wurde die insulinähnliche Aktivität verschieden behandelter menschlicher Seren mit und ohne Insulinantikörperzusatz bestimmt. Die niedrigsten Werte für die nichthemmbare ILA (entsprechend etwa $20-40 \mu \mathrm{E} / \mathrm{ml}$ Insulin) fanden sich, wenn die Seren in Luft mit $5 \% \mathrm{CO}_{2}$ präpariert wurden. Wurden die Seren in Luft präpariert oder wurde Heparin zugesetzt, stieg die nichthemmbare ILA an, während die hemmbare ILA, unverändert blieb. Hämoglobin $(0.1 \mathrm{mg} / \mathrm{ml}$ oder mohr) führte zu einer $\mathrm{Ab}$ nahme der hemmbaren, nicht iedoch der nichthemmbaren ILA. - Die nichthemmbare ILA des Rattenserums änderte sich mit dem Ermährungszustand der Tiere. Während des Fastens und unter einer fettreichen Diät sank sie ab. Dagegen ließ sich die Aktivität kristallinen Insulins und der nichthemmbaren ILA bei Zugabe zu Seren nüchterner oder mit Fett gefütterter Ratten quantitativ wiederfinden. - Verschiedene Behandlungsweisen des Serums führten zu einem Ansteigen der ILA. SäureAlkohol-Extraktion, Inkubation mit Heparin, ,warme Dialyse" und elektrophoretische Fraktionierung verursachten ein Ansteigen der nichthemmbaren ILA, nicht dagegen der hemmbaren II.A. - Die Ergebnisse zeigen, daß die nichthemmbare ILA im Nativserum vorhanden ist und wahrscheinlich eine physiologische Bedeutung hat. Die Auffassung, daß im Serum eine von hemmbarer ILA verschiedene Insulinform vorhanden ist, ließ sich nicht stützen.

Key-words: Non-suppressible ILA, suppressible ILA, insulin, isolated fat cells, heparin, haemoglobin.

\section{Introduction}

The serum insulin-like activity (ILA), measured by the epididymal fat pad method and the isolated fat cell method, is only partially inhibited by insulin antibodies $[49,18,24]$. The nature of the residual activity,

\footnotetext{
* Supported in part by: Nordisk Insulinfond.
}

the so-called non-suppressible ILA [18, 24] or "atypical" insulin [49], has been much debated. Two major questions are: 1. Is non-suppressible ILA of physiological significance? 2. Is it a modified form of insulin?

This report attempts to elucidate these questions. It was shown that the non-suppressible ILA was a variable factor, the activity of which depended on the 
circumstances under which serum was collected, prepared and stored. However, normal human sera, prepared in the most "gentle" way, always contained some non-suppressible ILA. In rats, this activity disappeared when the animals were fasted, or fed a high fat diet. This has led to the conclusion that the nonsuppressible ILA is probably a physiologically im. portant substance.

Sera were subjected to treatments which have been reported to convert one form of ILA to another as measured by the epididymal fat pad method. With the present assay system, many of the treatments caused an increase of the total ILA, but this was always due solely to a rise of non-suppressible ILA. These findings do not support the idea that non-suppressible ILA, or any other substance in serum, is a modified insulin from which biologically active "true" insulin can be released. pared from neck blood (rats, mice), from blood obtained by heart puncture (guinea pigs) or from blood obtained from venipuncture (other animals, humans). All sera had their glucose concentration adjusted to $2 \mathrm{mg}$ per $\mathrm{ml}$ and were assayed in the dilution $1: 10$. The lowest standard contained $1.25 \mu \mathrm{U}$ of insulin per $\mathrm{ml}$. Non-suppressible ILA values below the equivalent of $12.5 \mu \mathrm{U}$ per $\mathrm{ml}$ of serum were registered as zero. The suppressible ILA was regarded as zero when no significant difference $(p=0.05)$ was detected between incubations with and without antibodies. The oxygenation and deoxygenation was done by equilibrating the blood sample with either $95 \% \mathrm{O}_{2}-5 \% \mathrm{CO}_{2}$ or $95 \%$ $\mathrm{N}_{2}-5 \% \mathrm{CO}_{2}$.

The other treatments of the sera were performed according to the following references: incubation with adipose tissue extracts [4]; acid alcohol extraction a [26]; acid alcohol extraction b [15]; incubation with

Table 1. The suppressible and non-suppressible ILA of plasma and of serum prepared in different ways

The blood was taken from normal human subjects $45 \mathrm{~min}$ after oral glucose. The non-suppressible ILA was calculated as the mean of 4 values $\pm S$.D., the suppressible ILA as the difference between the total ILA and the mean of the non-suppressible ILA. 4 values $\pm S . D$.

\begin{tabular}{|c|c|c|c|c|c|}
\hline Serum & $\mathrm{ILA}(\mu \mathrm{U} / \mathrm{mI})$ & $\begin{array}{l}\text { Blood collected } \\
\text { in tube cooled on } \\
\text { ice, gas phase: } \\
95 \% \mathrm{O}_{2}-5 \% \\
\mathrm{CO}_{2}\end{array}$ & $\begin{array}{l}\text { Blood collected } \\
\text { in tube cooled on } \\
\text { ice, gas phase: } \\
\text { air }\end{array}$ & $\begin{array}{l}\text { Blood collected } \\
\text { in tube at room } \\
\text { temperature, gas } \\
\text { phase: air }\end{array}$ & $\begin{array}{l}\text { Plasma, blood } \\
\text { collected in tube } \\
\text { cooled on ice, } \\
\text { heparin: } 50 \mathrm{IU} \\
\text { ml gas phase: } \\
\mathbf{9 5 \%} \mathrm{O}_{2}-5 \% \mathrm{CO}_{2}\end{array}$ \\
\hline \multirow{2}{*}{$\mathbf{I}$} & Suppr. & $55 \pm 4$ & $61 \pm 3$ & $61 \pm 5$ & $51 \pm 10$ \\
\hline & Non-suppr. & $31 \pm 4$ & $49 \pm 3$ & $54 \pm 6$ & $97 \pm 7$ \\
\hline \multirow{2}{*}{ II } & Suppr. & $69 \pm 6$ & $67 \pm 4$ & $70 \pm 4$ & $77 \pm 11$ \\
\hline & Non-suppr. & $25 \pm 2$ & $31 \pm 3$ & $48 \pm 4$ & $81 \pm 6$ \\
\hline \multirow{2}{*}{ III } & Suppr. & $44 \pm 4$ & $43 \pm 3$ & $45 \pm 4$ & $49 \pm 6$ \\
\hline & Non-suppr. & $20 \pm 2$ & $34 \pm 3$ & $45 \pm 3$ & $57 \pm 6$ \\
\hline
\end{tabular}

\section{Material and Methods}

Male Wistar rats were fed normal laboratory chow ad libitum. Their weights were $110-130 \mathrm{~g}$ (for preparation of fat cells) or $180-200 \mathrm{~g}$ (for preparation of serum). Human insulin, (lot no. $41-4866,24.8 \mathrm{U}$ per $\mathrm{mg}$ as indicated by the factory on the basis of the nitrogen content) and guinea pig antibeef-insulin serum were gifts from the NOVO Research Institute. The antibodies were, unless otherwise indicated, used at a final concentration of $1: 5000$, which neutralized the activity of $60 \mu \mathrm{U}$ of human insulin per ml. Heparin (145 IU $/ \mathrm{mg}$ ) was obtained from Leo Pharmaceuticals. The sera were dialyzed in Visking tube, flat width $10 \mathrm{~mm}$. Otherwise, the material and chemicals used were identical to those described in a previous report [23].

The assays of insulin-like activity were carried out as previously described $[23,24]$. The sera were pre- heparin [27]; "warm dialysis" [21] and electrophoretic fractionation [34]. The electrophoretic separations of serum and the epididymal fat pad assay were performed by Dr. Lyngsøe, The NOVO Research Institute. Radioïmmunoassay of serum insulin was performed at the NOVO Research Institute according to the method of HEDING [29].

\section{Results}

The effect on the ILA of the preparation and storage of serum. Table 1 shows that the lowest values of nonsuppressible ILA were obtained when the serum was prepared in an atmosphere containing $5 \% \mathrm{CO}_{2}$. Plasma contained considerably more non-suppressible ILA than any of the serum preparations. In contrast to the variations in the non-suppressible ILA, the suppressible ILA remained constant. No difference was ob- 
served between sera prepared at $4^{\circ}$ and sera prepared at room temperature provided that the blood was taken in a precooled glass. If not, the non-suppressible ILA rose in some sera.

Table 2 shows that freezing and thawing 15 times quickly after each other had noeffect. Storage at $-20^{\circ} \mathrm{C}$ caused an increase of the ILA in the 3 sera tested after 1 and 3 months. All of the changes were due to increasing values of non-suppressible ILA. Storage at increase of the non-suppressible ILA to values similar to those of plasma (Fig. 1). The lowest active concentration of heparin was $0.25 \mathrm{IU}$ per $\mathrm{ml}$ and a maximal effect on the non-suppressible ILA was obtained with 1-10 IU per ml. Heparin added to buffer or buffer plus insulin had no effect.

It was observed that no suppressible ILA could be detected in sera which were haemolysed. Since haemolysis may occur in the preparation of sera, it was decided

Table 2. The suppressible and non-suppressible ILA of sera stored in different ways and for different periods of times

The blood was taken from normal human subjects $1-2 \mathrm{~h}$ after breakfast, and sera were prepared and stored with a gas phase of $95 \% \mathrm{O}_{2}-5 \% \mathrm{CO}_{2}$

\begin{tabular}{|c|c|c|c|c|c|c|}
\hline Serum & $\operatorname{ILA}(\mu \mathrm{U} / \mathrm{ml})$ & $\begin{array}{l}\text { Serum unfro- } \\
\text { zen, assayed } \\
2 \mathrm{~h} \text { after } \\
\text { preparation }\end{array}$ & $\begin{array}{l}\text { Serum frozen } \\
\text { and thawed } \\
\left(-15^{\circ} \mathrm{C}-\right. \\
\left.+37^{\circ} \mathrm{C}\right) 15 \\
\text { times with } 10 \\
\text { min interval }\end{array}$ & $\begin{array}{l}\text { Serum stored } \\
\text { for } 1 \text { month } \\
\text { at }-20^{\circ} \mathrm{C}\end{array}$ & $\begin{array}{l}\text { Serum stored } \\
\text { for } 3 \text { months } \\
\text { at }-60^{\circ} \mathrm{C}\end{array}$ & $\begin{array}{l}\text { Serumstored } \\
\text { for } 3 \text { months } \\
\text { at }-20^{\circ} \mathrm{C}\end{array}$ \\
\hline \multirow{2}{*}{ I } & Suppr. & $42 \pm 4$ & $40 \pm 2$ & $37 \pm 3$ & $37 \pm 4$ & $40 \pm 2$ \\
\hline & Non-suppr. & $27 \pm 3$ & $24 \pm 2$ & $38 \pm 2$ & $31 \pm 1$ & $41 \pm 2$ \\
\hline \multirow{2}{*}{ II } & Suppr. & $29 \pm 2$ & $32 \pm 3$ & $30 \pm 1$ & $29 \pm 1$ & $28 \pm 4$ \\
\hline & Non-suppr. & $24 \pm 1$ & $29 \pm 3$ & $40 \pm 2$ & $29 \pm 3$ & $39 \pm 2$ \\
\hline \multirow{2}{*}{ III } & Suppr. & $18 \pm 3$ & $25 \pm 4$ & $16 \pm 3$ & $18 \pm 3$ & $16 \pm 2$ \\
\hline & Non-suppr. & $44 \pm 3$ & $36 \pm 4$ & $61 \pm 3$ & $40 \pm 1$ & $68 \pm 2$ \\
\hline
\end{tabular}

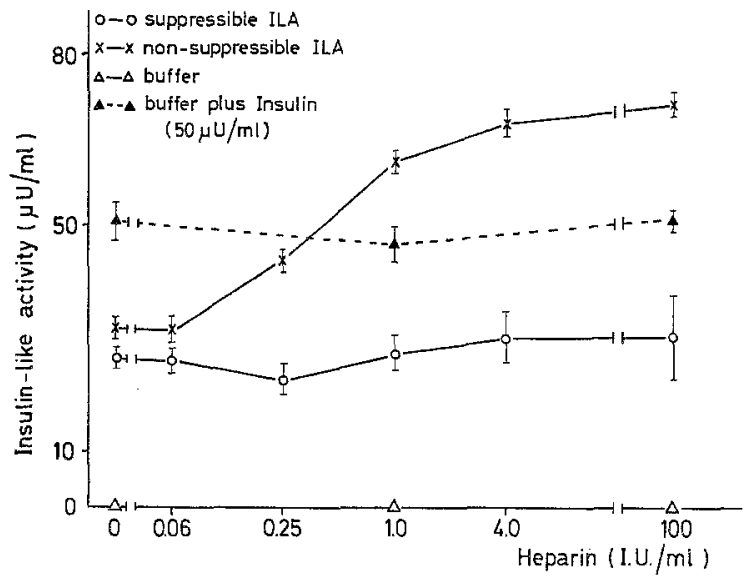

Fig. 1. The effect of heparin on the ILA of human serum The indicated amount of heparin was added to $1 \mathrm{ml}$ of serum in a volume of $20 \mu l$ and the samples were allowed to shake for $1 \mathrm{~h}$ at room temperature just prior to the assay. Each value represents the mean of 4 incubations \pm S.D.

$-50^{\circ} \mathrm{C}$ for up to 3 months had no effect on the ILA. The changes were due to increases of non-suppressible ILA, and no significant variation of the suppressible ILA was detected. The sera used in the following studies were stored at $-20^{\circ} \mathrm{C}$ for not more than one month.

Addition of heparin $(50 \mathrm{IU} / \mathrm{ml})$ to serum caused an

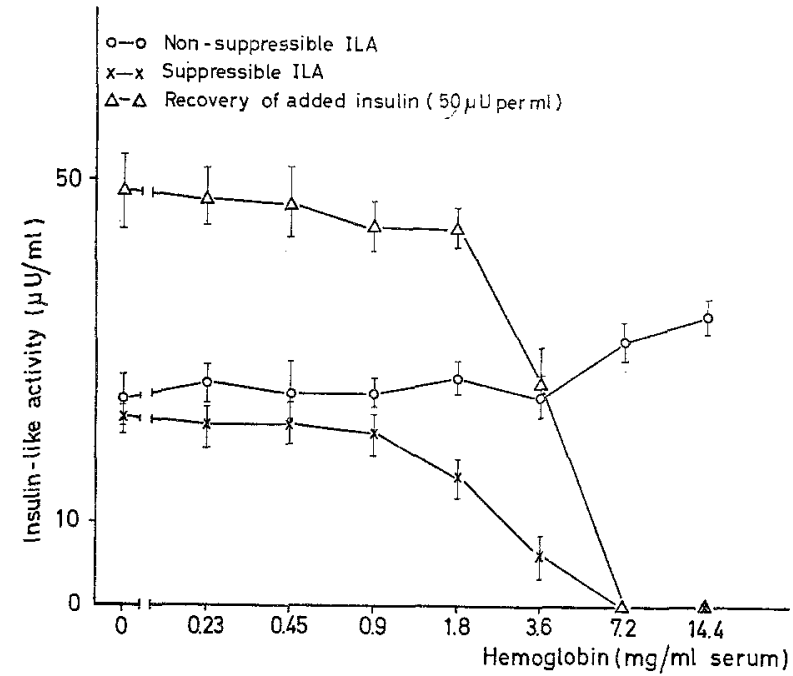

Fig. 2. The effect of human haemoglobin on the ILA of human serum

A haemoglobin solution was prepared by addition of 1.5 volume of distilled water to 1 volume of blood containing $144 \mathrm{mg}$ of haomoglobin per ml. The resulting solution was adjusted to contain $2 \mathrm{mg}$ of glucose per $\mathrm{ml}$ and mixed with 3 volumes of serum. $100 \mu \mathrm{l}$ of this serum, now containing $14.4 \mathrm{mg}$ of haemoglobin per $\mathrm{ml}$, was assayed with $900 \mu \mathrm{l}$ of cell suspension. Distilled water added to the serum in the same concentration as the haemoglobin solution, had no marked effect on the ILA and no effect on the recovery of crystalline insulin. - Each value represents the mean of 4 incubations $\pm S . D$. 
to investigate the effect of haemoglobin systematically. Fig. 2 shows that human haemoglobin in final concentrations of less than $0.05 \mathrm{mg}$ per $\mathrm{ml}$ had no effect on suppressible or non-suppressible ILA, whereas a final concentration of $0.7 \mathrm{mg}$ per $\mathrm{ml}$ completely depressed the activity of suppressible ILA and crystalline insulin but not the activity of non-suppressible ILA.

There was no difference in the suppressible or nonsuppressible ILA of untreated oxygenated or deoxygenated human venous blood. There were no consistent differences between rabbit venous and arterial blood nea pig serum contained none of this activity. All of the 20 rat sera contained non-suppressible ILA when assayed with cells from littermates or, in some cases, with cells prepared from their own fat pads (Table 3).

Variations in the non-suppressible ILA of rat serum. The non-suppressible ILA of rat serum was unchanged after a glucose load given by stomach tube $(0.5 \mathrm{~g} / 100 \mathrm{~g}$ rat). However, fasting diminished the non-suppressible activity, and none was detected after 2 days (Fig. 3). After refeeding, some activity was found after $12 \mathrm{~h}$

Table 3. The suppressible and non-suppressible ILA of serum taken from various mammals

The number of animals used is given in the bracket. The blood from 4 mice had to be pooled in order to give enough serum for one assay. - The activities were determined with 4 replicates for each animal. The numbers indicate the mean value for the different animals, and, if 4 or more animals were used, \pm S.D.

\begin{tabular}{llllllll}
\hline $\begin{array}{l}\text { ILA } \\
(\mu \mathrm{U} / \mathrm{ml})\end{array}$ & $\begin{array}{l}\text { Rat } \\
(20)\end{array}$ & $\begin{array}{l}\text { Mouse } \\
(4 \times 4)\end{array}$ & $\begin{array}{l}\text { Guinea } \\
\text { piga }^{\mathrm{a}}\end{array}$ & $\begin{array}{l}\text { Rabbit } \\
(4)\end{array}$ & $\begin{array}{l}\text { Dog } \\
(3)\end{array}$ & $\begin{array}{l}\text { Cat } \\
(3)\end{array}$ & $\begin{array}{l}\text { Goat } \\
(1)\end{array}$ \\
\hline $\begin{array}{l}\text { Suppr. } \\
31 \pm 9\end{array}$ & 0 & 0 & $23 \pm 5$ & 39 & 28 & 18 \\
\hline Non-suppr. & $27 \pm 7$ & $38 \pm 6$ & 0 & $31 \pm 7$ & 41 & 57 & 21 \\
\hline
\end{tabular}

a Serum slightly haemolysed.

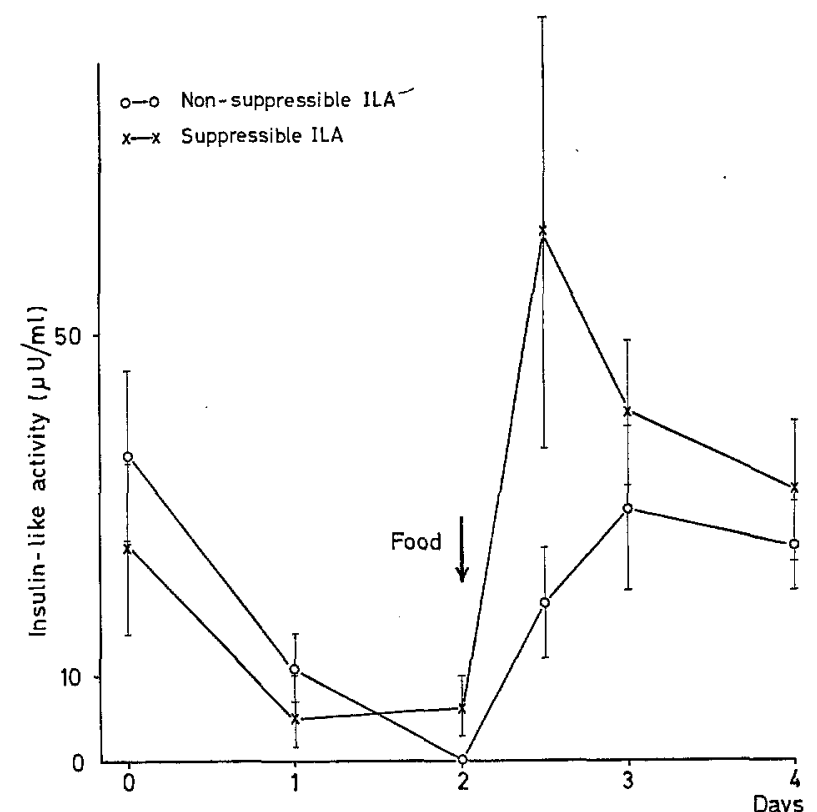

Fig. 3. The effect of fasting and refeeding of rats on the serum ILA

The suppressible and non-suppressible ILA was assayed with 4 replicate values for each rat. The points represent the mean values of serum from 5 animals 1 S.D.

treated identically. It was observed that especially the rabbit blood haemolysed very easily during gassing.

The non-suppressible ILA of different species. Sera prepared from a number of mammals had roughly similar values of non-suppressible ILA. However, gui-
Table 4. The effect of the diet on the suppressible and nonsuppressible IL $A$ of rat serum

Rats of about $150 \mathrm{~g}$ were given the various diets for 2 weeks. The serum was prepared from neck blood and the activities were determined with 4 replicates. Each group consisted of 5 animals and the results are indicated as the means of the values for the individual animals \pm S.D.

\begin{tabular}{lllc}
\hline \multicolumn{1}{c}{$\begin{array}{l}\text { Normal } \\
\text { diet. }\end{array}$} & Oat meal. & $\begin{array}{l}\text { Oat meal } \\
+25 \% \\
\text { olive oil. }\end{array}$ & $\begin{array}{l}\text { Oat meal } \\
+50 \% \\
\text { olive oil. }\end{array}$ \\
\hline $\begin{array}{l}\text { Weight gain } 44 \pm 15 \\
\text { (g/animal) }\end{array}$ & $25 \pm 5$ & $22 \pm 15$ & $9 \pm 7$ \\
\hline $\begin{array}{l}\text { Suppr. ILA } \\
\text { ( } 20 \pm \mathrm{U} / \mathrm{ml})\end{array}$ & $21 \pm 8$ & $17 \pm 8$ & $12 \pm 10$ \\
\hline $\begin{array}{l}\text { Non-suppr. } 36 \pm 5 \\
\text { ILA ( } \mu \mathrm{U} / \mathrm{ml})\end{array}$ & $34 \pm 6$ & 0 & 0 \\
\hline
\end{tabular}

and the previous level was reached after $24 \mathrm{~h}$. The suppressible ILA declined during fasting and rose during refeeding to higher values than before the fasting.

Table 4 shows the ILA of serum from rats fed different diets. There was no difference between sera from rats fed the usual food pellets and rats fed oat meal. No non-suppressible ILA was detected when the rats had been fed oat meal plus 25 or 50 per cent olive oil (about 35 or 70 per cent of the calories as fat) for 2 weeks. There was no significant difference between the suppressible ILA of these different groups. Both the control animals and those fed oat meal plus 25 per cent olive oil gained in weight, whereas the 
animals fed 50 per cent oil showed a slight weight loss during the period.

A possible explanation of these changes would be that an ILA inhibitor was present in serum from fasted. or fat fed rats. However, both suppressible and nonsuppressible ILA of normal rat serum and of human inactivated after adjustment of the serum to $\mathrm{pH} 12$. Heating of the serum to $70^{\circ} \mathrm{C}$ inactivated the suppres. sible ILA but not the non-suppressible ILA. Some of the treatments were considered of particular interest since they have been dealt with in several previous studies and have provided much of the experimental

Table 5. The effect on ILA of various treatments of human serum

Each value represent the mean of 4 incubations \pm S.D.

\begin{tabular}{|c|c|c|c|c|c|c|c|c|c|}
\hline $\mathrm{ILA}(\mu \mathrm{U} / \mathrm{ml})$ & $\begin{array}{l}\text { A: Native } \\
\text { serum }\end{array}$ & $\begin{array}{l}\mathrm{B}: \text { Heating } \\
\text { to } 70^{\circ} \mathrm{C} \text { for } \\
10 \text { minutes }\end{array}$ & $\begin{array}{l}\mathrm{C}: \text { Adjust- } \\
\text { ment to } \\
\text { pH } 3.0 \text {, } \\
\text { back to } \\
\text { pH } 7.4\end{array}$ & $\begin{array}{l}\text { D : Adjust- } \\
\text { ment to } \\
\text { pH } 10.0 \text {, } \\
\text { back to } \\
\text { pH } 7.4\end{array}$ & $\begin{array}{l}\text { E: Adjust- } \\
\text { ment to } \\
\text { pH } 12.0 \text {, } \\
\text { back to } \\
\text { pH } 7.4\end{array}$ & $\begin{array}{l}\text { F: Dialy- } \\
\text { sis against } \\
\text { buffer, } \\
\text { pH } 7.4 \text { at } \\
22^{\circ} \mathrm{C} \text { for } \\
24 \mathrm{~h}\end{array}$ & $\begin{array}{l}\mathrm{G} \text { : Dialy- } \\
\text { sis against } \\
\mathrm{H}_{2} \mathrm{O} \text { at } \\
22^{\circ} \mathrm{C} \text { for } \\
24 \mathrm{~h}\end{array}$ & $\begin{array}{l}\text { H: Lyo- } \\
\text { philization } \\
\text { and recon- } \\
\text { stitution }\end{array}$ & $\begin{array}{l}\text { I: Incuba- } \\
\text { tion with } \\
\text { adipose tis- } \\
\text { sue ox- } \\
\text { tract }\end{array}$ \\
\hline Suppr. & $31 \pm 3$ & 0 & $27 \pm 3$ & $24 \pm 3$ & 0 & $19 \pm 3$ & $17 \pm 4$ & $33 \pm 4$ & $32 \pm 4$ \\
\hline Non-suppr. & $29 \pm 3$ & $33 \pm 4$ & $61 \pm 4$ & $89 \pm 4$ & 0 & $59 \pm 5$ & $91 \pm 7$ & $49 \pm 4$ & $31 \pm 3$ \\
\hline
\end{tabular}

Table 6. The effect on the ILA of acid alcohol extraction, "warm dialysis" and heparin treatment of serum

Sera were prepared from blood obtained from normal human subjects a few hours after breakfast. In some incubations $50 \mu \mathbf{U}$ of crystalline insulin was added to the sera and the recoveries are indicated. Each value represents the mean of 4 incubations $\pm S . D$.

\begin{tabular}{|c|c|c|c|c|c|}
\hline \multirow[b]{2}{*}{ Serum } & \multirow{2}{*}{$\begin{array}{l}\mathrm{ILA} \\
(\mu \mathrm{U} / \mathrm{ml})\end{array}$} & \multicolumn{4}{|c|}{ Human serum } \\
\hline & & $\mathrm{I}$ & II & III & IV \\
\hline \multirow{3}{*}{ Native } & Suppr. & $20 \pm 5$ & $31 \pm 3$ & $44 \pm 4$ & $24 \pm 3$ \\
\hline & Non-suppr. & $40 \pm 3$ & $37 \pm 3$ & $25 \pm 3$ & $21 \pm 2$ \\
\hline & Recovery & $57 \pm 6$ & $61 \pm 7$ & $51 \pm 4$ & $49 \pm 3$ \\
\hline \multirow{3}{*}{$\begin{array}{l}\text { Acid } \\
\text { Alcohol } \\
\text { extr. } 1 .\end{array}$} & Suppr. & $16 \pm 4$ & $22 \pm 4$ & $40 \pm 4$ & $18 \pm 3$ \\
\hline & Non-suppr. & $30 \pm 5$ & $30 \pm 6$ & $25 \pm 5$ & $16 \pm 3$ \\
\hline & Recovery & $39 \pm 7$ & $49 \pm 5$ & $47 \pm 5$ & $42 \pm 3$ \\
\hline \multirow{3}{*}{$\begin{array}{l}\text { Acid } \\
\text { Alcohol } \\
\text { extr. } 2 .\end{array}$} & Suppr. & 0 & 0 & $21 \pm 4$ & 0 \\
\hline & Non-suppr. & $89 \pm 8$ & $98 \pm 10$ & $71 \pm 7$ & $49 \pm 3$ \\
\hline & Recovery & $23 \pm 2$ & 0 & $43 \pm 2$ & 0 \\
\hline \multirow{3}{*}{$\begin{array}{l}\text { "Warm } \\
\text { dialysis" }\end{array}$} & Suppr. & 0 & $19 \pm 4$ & $40 \pm 3$ & 0 \\
\hline & Non-suppr. & $150 \pm 10$ & $83 \pm 6$ & $56 \pm 4$ & $69 \pm 5$ \\
\hline & Recovery & 0 & 0 & $31 \pm 3$ & 0 \\
\hline \multirow{3}{*}{$\begin{array}{l}\text { Incub. } \\
\text { with } \\
\text { heparin }\end{array}$} & Suppr. & $26 \pm 5$ & $37 \pm 3$ & $35 \pm 3$ & $28 \pm 3$ \\
\hline & Non-suppr. & $130 \pm 10$ & $114 \pm 8$ & $60 \pm 5$ & $71 \pm 4$ \\
\hline & Recovery & $67 \pm 6$ & $57 \pm 4$ & $40 \pm 3$ & $41 \pm 2$ \\
\hline
\end{tabular}

serum was recovered quantitatively in sera containing no non-suppressible ILA.

Increases of ILA caused by treatments of serum. Table 5 and 6 show an increased ILA after various treatments of human sera. However, both suppressible and non-suppressible ILA were unchanged after treatment with adipose tissue extracts. It must also be noted that the non-suppressible ILA was completely basis for the concept of a serum insulin different from the free form. Table 6 shows a more detailed study of sera from 4 normal humans subjected to two different acid alcohol extractions, to incubation with heparin and to "warm dialysis". Little change was observed after extraction of serum by the method of Gropsky and Forsham [26]. Between 70 and 90 per cent of both suppressible ILA, non-suppressible ILA and ad- 
ded crystalline insulin was recovered. Extraction by the method of Davidson [15] caused a 2-3 fold increase of the non-suppressible ILA. The suppressible ILA and the added insulin were only partially recovered. The results of "warm dialysis" of serum were very similar. Finally, a marked increase of the nonsuppressible ILA was observed after incubation of the serum with heparin. Suppressible ILA and added insulin were quantitatively recovered in this case.

Table 7 shows the effect of electrophoretic separation of serum on the ILA. Both the faster moving fraction (A fraction) and the slower moving fraction agreement with the present results, which in addition show that only the non-suppressible ILA rose.

The effect of small amounts of heparin (Fig. 1) indicates that some types of experiments have to be evaluated with caution. The small amounts of heparin which are often used in physiological experiments to keep catheters open, may well cause a blood concentration of heparin sufficiently high to influence the ILA. The further implications of the effect of heparin are discussed below.

Haemoglobin in concentrations of about $0.1 \mathrm{mg}$ per $\mathrm{ml}$ or more, depressed the activity of suppressible

Table 7. The effect on the ILA of electrophoretically separation of serum

A fraction: albumin $\alpha$ globulin, B fraction: $\beta-\gamma$ globulin. The fat pad assay on the fractions was carried out in the dilution $1: 20$, the isolated fat cell assays in the final dilution $1: 40$. Undiluted guinea pig anti-insulin serum was used in both types of assay. O insulin indicates that less than $40 \mu \mathrm{U}$ of suppressible ILA was present in the fraction. In some experiments, $50 \mu \mathrm{U}$ of crystalline insulin was added to $1 \mathrm{ml}$ of fraction just prior to the assay and the recovery is indicated. Each value represents the mean of 4 incubations \pm S.D.

\begin{tabular}{|c|c|c|c|c|c|c|c|}
\hline \multirow[t]{3}{*}{ Exp. no. } & \multirow[t]{3}{*}{ Assay } & \multicolumn{6}{|c|}{ ILA $(\mu \mathrm{U} / \mathrm{ml})$} \\
\hline & & \multicolumn{3}{|c|}{ A Fraction } & \multicolumn{3}{|c|}{ B Fraction } \\
\hline & & suppr. & non-suppr. & recovery & suppr. & non-suppr. & recovery \\
\hline 1. & Isol. cells & 0 & $134 \pm 7$ & - & 0 & $240 \pm 9$ & - \\
\hline 2. & Isol. colls & 0 & $151 \pm 9$ & $32 \pm 6$ & 0 & $101 \pm 9$ & $36 \pm 5$ \\
\hline 3. & Isol. cells & 0 & $87 \pm 7$ & $28 \pm 2$ & 0 & $93 \pm 6$ & $38 \pm 4$ \\
\hline \multirow{2}{*}{4.} & Isol. cells & 0 & $89 \pm 7$ & - & 0 & $183 \pm 11$ & - \\
\hline & Fat pad & 1060 & 340 & - & 0 & 460 & - \\
\hline
\end{tabular}

Native serum: $\left\{\begin{array}{l}\text { ILA, Fat Pad assay: } 156 \mu \mathrm{U} / \mathrm{ml} \\ \text { ILA, Isolated cells }\left\{\begin{array}{l}\text { suppressible: } 41 \pm 4 \mu \mathrm{U} / \mathrm{ml} \\ \text { non-suppressible: } 24 \pm 2 \mu \mathrm{U} / \mathrm{ml}\end{array}\right. \\ \text { Immunoreactive insulin: } 54 \mu \mathrm{U} / \mathrm{ml}\end{array}\right.$

(B fraction) contained more non-suppressible ILA than the original serum, as measured in the fat pad assay or the isolated cell assay. The A fraction contained $1060 \mu \mathrm{U}$ of suppressible ILA measured by the epididymal fat pad method, and yet this activity could not be demonstrated with the isolated fat cell technique. Crystalline insulin added to the fractions was only partially recovered.

\section{Discussion}

Considerations on the preparation and handling of serum. LYNGSøE found the lowest values of ILA when the serum was prepared and stored at $4^{\circ} \mathrm{C}$ and assayed the same day [33]. Storage at room temperature (air gas phase), and repeated freezing and thawing caused an increase of total ILA. The effect of storage in the frozen state was investigated by Powar et al. [39]. After storage for 3 months at $-20^{\circ} \mathrm{C}$ they found a 4 -fold increase of the ILA of undiluted serum and doubling of the ILA of serum diluted $1: 10$. This is in
ILA (Fig. 2). Since the assays were carried out in the dilution $1: 10$, this corresponds to a concentration of $1.0 \mathrm{mg}$ of haemoglobin per $\mathrm{ml}$ of serum. Such serum is distinctly pink. Undiluted serum is frequently used in the epididymal fat pad assay. The presence of 0.1 $\mathrm{mg}$ of haemoglobin per $\mathrm{ml}$ of serum will hardly be observed with the naked eye. However, the effect of haemoglobin on the suppressible ILA measured by the fat pad method has, to our knowledge, not been investigated.

Some authors have demonstrated an increased ILA (diaphragm and fat pad methods) after oxygenation of venous blood, and a decrease after deoxygenation [59, 46]. Others have been unable to detect such differences with the fat pad method [50] or with a radio-immuno method [51]. The reason for the different results is unknown, $\mathrm{pH}$ changes of the serum or slight haemolysis may play a role in some samples.

Non-suppressible ILA in sera from various animals and its physiological significance. STEINK. et al. [57], 
using rat adipose tissue, found a relatively high total ILA in rat serum, a lower ILA in mouse serum and no significant ILA in guinea pig serum. On the other hand, SallaAN et al. found non-suppressible ILA present in guinea pig serum [48]. The highest reported ILA values were found in diluted sera from fish [12]. However, it is obvious that the results of non-suppressible activity of serum from one species measured on adipose tissue from another species must be evaluated with great caution. It was felt particularly important, therefore, to establish that sera from fed rats, prepared as "gently" as possible, actually did show a consistent nonsuppressible ILA on isolated fat cells prepared from similar rats (Table 3 )

The fact that non-suppressible ILA is active on isolated fat cells, on epididymal fat pads in vitro and probably on epididymal fat after intraperitoneal injection [11], might lead to the conclusion that it must be of physiological significance. However, it must be remembered that adipose tissue is rather labile and increases its glucose metabolism due to several nonhormonal factors such as prolonged incubation in vitro $[30,36]$, incubation in hyperosmotic buffer [32] or division of the tissue into smaller segments [31]. At least two more features must be established before it can be postulated that the non-suppressible ILA is involved in the regulation of the glucose metabolism in vivo: it must be active when supplied to the tissue from the capillaries, and it must show variations with different metabolic states. There is some evidence on the former point. The purified non-suppressible ILA of Fromscr and coworkers [19] and the "bound insulin" of AnTonIaDes [2] are both reported to be active after intravenous injection. However, it is uncertain whether these substances are identical to the native non-suppressible ILA. On the other hand, Partanian and coworkers [38] and RAsro and coworkers [44] found only one fifth of the serum ILA in mesenteric lymph of rats and most of the remaining ILA was immunoreactive. However, the mesenteric lymph is hardly representative of the interstitial fluid of adipose tissue.

The variation with different metabolic states was illustrated by the finding that the non-suppressible ILA disappeared after fasting or fat feeding of the rats (Fig. 3, Table 4). The effect of fasting on the ILA of rat serum, as measured by the epididymal fat assay, has been investigated with conflicting results. PARTAMIAN and coworkers found a decrease of the ILA to about half after $3-6$ days of fasting [38]. The data on immunoreactive insulin suggested that most of the suppressible ILA had disappeared but only about a third of the non-suppressible ILA. On the other hand, SAMAaN et al. [47] found a complete disappearance of suppressible and non-suppressible ILA in rats after 7 days of fasting. In the present experiments, the non-suppressible ILA disappeared after fat feeding of rats despite the fact that the animals, when 35 per cent of the calories were supplied as fat, gained in weight and maintained a normal level of suppressible ILA (Table 4). It is noteworthy that the metabolism had changed from predominantly carbohydrate to largely fat under the conditions where the non-suppressible ILA disappeared from serum. The variation of the nonsuppressible ILA with the metabolic state of rats suggests that it is a factor of physiological significance.

Is non-suppressible ILA a form of insulin? SAMAAN and coworkers separated suppressible ILA from nonsuppressible ILA by ultrafiltration and subjected the latter to acid-alcohol extraction according to the method of Grodsky and Forsham [26]. After 24h of extraction, between one and two thirds of the nonsuppressible ILA was converted to suppressible ILA [49]. Moloney found an increase of "free" insulin (diaphragm method) after a similar treatment of the sera [37]. Using the same extraction procedure, between 70 and 90 per cent of both suppressible and non-suppressible ILA was recovered with the isolated fat cell method (Table 4).

Other experiments related to the problem of whether or not non-suppressible ILA is a form of insulin have yielded conflicting results. Some have found a persistence of the ILA after pancreatectomy [58, 52], others a disappearance $[56,21]$. Some have found a conversion of suppressible ILA to non-suppressible ILA in the liver [50] whereas others have been unable to confirm this $[9,55]$. It is noteworthy that BüRGI and coworkers found no insulin A chain in purified nonsuppressible ILA [10]. Together, these findings do not support the hypothesis that the non-suppressible ILA is or contains a form of insulin.

Is insulin present in any other form than as suppressible ILA? DAVIDSON and coworkers introduced an acid-alcohol extraction method by which up to 7000 $\mu \mathrm{U}$ of ILA could be recovered from $1 \mathrm{ml}$ of serum [15]. The activity on the mouse diaphragm was not depressed by the addition of anti-insulin serum, and the extracted serum contained no insulin as measured by radioimmunoassay [7]. However, the authors believed that the values represented the total recoverable insulin in serum [15] since they found an increase of this ILA after ingestion of glucose and a disappearance after pancreatectomy [14]. PowER, using the same extraction technique, also found an increase after oral glucose [40]. However, the data could be interpreted as an increase of suppressible ILA over and above a constant level of extracted non-suppressible ILA. In the present experiments, a moderate increase of nonsuppressible ILA was found after this acid-alcohol extraction. Suppressible ILA and added crystalline insulin were only partially recovered (Table 6 ).

Treatment of serum with heparin is believed to convert so called "bound insulin", which is inactive on the diaphragm, to "free insulin", which is active on this tissue $[27,28]$. The results here show that if "free insulin" was released, it was still non-suppressib- 
le in the isolated fat cell system. "Bound insulin" prepared by adsorption to Dowex-50 W resin is, according to the original workers, active on the epididymal fat pad $[4,1]$. It has been reported to be partially suppressed by anti-insulin serum after treatment with adipose tissue extract [53] or acid alcohol $[5,53]$. Others have found very little activity on fat pads of bound insulin prepared this way, and have been unable to demonstrate release of suppressible ILA [20] or immunoreactive insulin [7]. In the present experiments, adipose tissue extracts had no effect on the two forms of ILA (Table 5).

The existence of more than one form of insulin in blood serum was strongly suggested by experiments with sera treated by "warm dialysis" or electrophoretic separation. GJEDDE subjected sera to dialysis against distilled water at $37^{\circ} \mathrm{C}$ for several days. The resulting suspension contained about 1000-fold more ILA than the original serum [21]; and, moreover, up to 90 per cent could be suppressed by addition of insulin antibodies [22]. LYNGSøE dialyzed serum against buffer at $20^{\circ} \mathrm{C}$ and fractionated it by electrophoresis on pevicon block. Both the faster moving fraction (A fraction) and the slower moving fraction (B fraction) contained much more suppressible ILA and nonsuppressible ILA than the original undiluted serum [34, Table 7]. Others have obtained similar results [17; for review see 35]. There is strong evidence, therefore, that electrophoretic fractionation of serum causes a marked increase in suppressible ILA as measured by the fat pad method. In contrast, the isolated fat cells did not detect an increased level of suppressible ILA in sera subjected to these treatments, although a variable increase in non-suppressible ILA was observed.

What causes the difference between the fat pad method and the fat cell method? The possibility that the suppressible ILA "released" by the various treatments is active on the epididymal fat pad but not on the free fat cell seems highly unlikely for several reasons: the free fat cells were prepared from epididymal fat pads of the same strain of rats as those used in the fat pad assay; the isolated cells show, as do the epididymal fat pads, an increased glucose metabolism in response to insulin and to other hormones [45], to non-suppressible ILA of native and treated sera and to non-hormonal factors $[30,36,32,31]$. Furthermore, the biological activities of crystalline insulins from different species [23] and of insulin-derivatives [8] are roughly the same with the two methods. The suppressible ILA of treated serum should be, therefore, a peculiar exception.

The activity of small amounts of suppressible ILA of treated serum and serum fractions may be augmented in the fat pad system. The hypothesis is supported by the findings that the activity of crystalline insulin and suppressible ILA is markedly augmented (order of magnitude: 4 fold) in dilute human serum from normal persons [43] and in protein fractions of human serum prepared on DEAE-cellulose [41, 42]. There is no augmentation of suppressible ILA and of crystalline insulin in dilute human serum when assayed by the isolated fat cell method [24]. Part of the mechanism of the augmentation in the epididymal fat pad system may be the following:

1. Adipose tissue [3] or extracts thereof [16], inactivates large amounts of insulin under conditions such as those employed for assay. Isolated fat cells, as they are used for the assay, do not inactivate insulin to a significant degree [25]. The "bound" insulin of ANTONIADES diminishes removal from the medium of crystalline insulin by epididymal fat pads [3]. This may also be true for factors present in the treated sera and, if so, this would cause an augmentation in the activity of small amounts of insulin in the sera in relation to the standard curve.

2. Interstitial diffusion of glucose is a rate limiting step in the glucose metabolism of fat pads from fed rats, in particular in the presence of insulin [13]. Therefore, a factor which enhances the diffusion of glucose would cause an apparent increase in both suppressible and non-suppressible ILA.

3 . Isolated fat cells are about 10 times more sensitive to insulin than fat pads [25]. It seems possible that this difference is caused by a restriction of insulin diffusion into the tissue combined with the inactivation of insulin. If so, factors which increase interstitial diffusion of insulin would cause an augmentation of suppressible ILA.

Still other possibilities which may be of significance in some fat pad assays are: haemoglobin or other inhibitors of suppressible ILA may be removed by the treatments; antiinsulin serum may depress the basal glucose metabolism of fat pads [6], possibly due to a reaction of the antibodies with insulin within the tissue; and the correct dose-response relationship may be different from the straight line which is drawn between the highest and lowest dose of insulin in the fat pad assays [54].

It seems reasonable to conclude that an increased level of suppressible ILA (fat pad method) or "free" insulin (diaphragm method), does not necessarily mean that more insulin is "released" or "unmasked". The finding that such changes cannot be detected with the isolated fat cell method makes it improbable. We must, therefore, consider the existence of more than one form of insulin with biologically significance in serum as unproven.

Acknowledgement. The author wishes to thank Dr. LynGsøe, NOVO Research Institute, for performing the serum electrophoresis and the fat pad assay. - Miss J. WICHMANN is thanked for skilled technical assistance.

\section{References}

1. Antontades, H.N.: Studies on the state of insulin in blood: The state and transport of insulin in blood. Endocrinology 68, $7-16$ (1961). 
2. - Rat serum "bound" insulin. In vivo biologic effects in rats. Diabetes 15, $889-893$ (1966).

3. - , and S.N. GershowF: Inhibitory effects of "bound" insulin on insulin uptake by isolated tissues. Diabetes 15, 655-662 (1966).

4. - , and K. GUNDerser: Studies on the state of insulin in blood: Dissociation of purified human blood insulin complex(es) by incubation with adipose tissue extracts in vitro. Endocrinology 68, 36-42 (1961).

5. - - Studies on the state of insulin in blood: Properties of circulating "free" and "bound" insulin. Endocrinology 76, 709-721 (1965).

6. Beloff-Chatr, A., R. Catanzaro, and E.B. Chain: Influence of anti-insulin serum on glucose metabolism. I. In isolated adipose tissue. Diabetes $\mathbf{1 6}$, $472-474(1967)$.

7. Berson, S.A., and R. S. Yalow: Insulin in blood and insulin antibodies. Amer. J. Med. 40, 676-690 (1966).

8. Brunfeidt, K., B.A. Hansen, and K.R. JørGenSEN: The immunological reactivity and biological activity of iodinated insulin. Acta endocr. (Kbh.) In print.

9. BÜrgr, H., K. Kopetz, K. Schwarz, and E.R. FroEsch: Fate of rat insulin in rat liver perfusion studied by adipose tissue assay. Lancet 1963 II, $314-316$.

10. - W.A. MÜller, R.E. Humbel, A. Labhart, and E.R. Fromsch: Non-suppressible insulin-like activity of human serum. I. Physico-chemical properties, extraction and partial purification. Biochim. biophys. Acta 121, 343--359 (1966).

11. Cahili, G.F., V. Laturis, J.S. Soeloner, D. Slone, and J. STEINKE: Assay of serum insulin and insulinlike activity on adipose tissue and muscle in vivo. Metabolism 13, $769-774(1964)$.

12. - L. Tashima, V. LauRis, J.S. Soeldner and J. STEINKE: Some observations on insulin in toadfish (opsanus tau). In: Brolin, HellmaN and KNUTSON: The structure and metabolism of the pancreatic islets, p. 243-247. Oxford: Pergamon Press 1964.

13. Crofford, O.B., and A. E. Renotd : Glucose uptake by incubated rat epididymal adipose tissue. Ratelimiting steps and site of insulin action. J. biol. Chem. 240, 14-21 (1965).

14. Dayidson, J.K., M.A. Ashworth, B.J. Lin, A.M. RAPPOPORT, and R.E. HATST: Serum insulin activity in dogs and in man. In: Fifth Congress of the International Diabetes Federation, Excerpta Med. p. 40, Abstract. Amsterdam: 1964.

15. - R.E. HAIST, and C.H. Bast: Studies employing a new method for the recovery of biologically active insulin from acid alcoholic extracts of pancreas and blood serum. Diabetes 12, 448-453 (1963).

16. Di Grrolamo, M., D. Rudmann, M.F. Malkin, and L.A. Gracta: Inactivation of insulin by adipose tissue. Diabetes 14, 87-92 (1965).

17. Ditschuneit, H., R. Cuendet, and E.P. Pfeiffer: Activité insulinique des fractions protéiniques du sérum humain normal. Path. Biol. 12, 148-160 (1964).

18. Froesch, E.R., H. Bürgi, E. B. Ramserr, P. Batity, and A. LABHART: Anti-body-suppressible and nonsuppressible insulin-like activity in human serum and their physiologic significance. J. clin. Invest. 42, $1816-1834$ (1963).

19. - W.A. Mütreer, H. BürGr, M. VALDVoGEr, and A. LABHART: Non-suppressible insulin-like activity of human serum. II. Biological properties of plasma extracts with non-suppressible insulin-like activity. Biochim. biophys. Acta 121, 360-374 (1966).
20. Gener-Segui, J., and A.J. Wolfe: Studies of "bound" insulin by epididymal fat pad assay. Diabetes 15, 894-900 (1966).

21. GJEDDE, F.: Effect of glucose on the insulin-like activity of serum from $v$. pancreaties-duodenalis and from a. femoralis in dogs. In: Brolin, Hellman and Knutson: The structure and metabolism of the pancreatic islets, p. 469-475. Oxford: Pergamon Press 1964.

22. - Studies of the insulin-like activity of serum II. Characterisation of insulin-like activity of serum protein fractions from normal human subjects. Acta endocr. (Kbh.) in print.

23. Glimmann, J.: Assay of insulin-like activity by the isolated fat cell method. I. Factors influencing the response to crystalline insulin. Diabetologia 3, 382388 (1967)

24. - Assay of insulin-like activity by the isolated fat cell method. II. The suppressible and non-suppressible insulin-like activity of serum. Diabetologia 3, $389-394$ (1967).

25. - Glucose metabolism and insulin response of isolated fat cells and epididymal fat pads. Acta physiol. scand., in print.

26. Grodsky, G.M., and P.H. Forsham: An immunochemical assay of total extractable insulin in man. J. clin. Invest. 39, 1070-1079 (1960).

27. GUNDERSEN, K., and B.J. LiN : Effect of heparin on insulin complexes. Tufts Folia Med. 8, 17-19 (1962).

28. - - Effect of heparin on insulin-like activity in rat bioassay. Comparison between rat diaphragm and epididymal fat in normal untreated diabetic sub. jects. Diabetes 14, 805-810 (1965).

29. Heding, L.: Ethanol precipitation as a substitute for the double antibody reaction in a simplified insulin immunoassay method. Diabetologia 1, 76 (Abstract) (1965)

30. Herrera, M.G., G.R. Philtipps, and A.E. RE. NOLD: Stimulation of metabolie aetivity of adipose tissue from fasted rats by prolonged incubation in vitro. Biochim. biophys. Acta 106, $221-233$ (1965).

31. KraHL, M.E.: The action of insulin on cells, p. 183. New York and London: Academic press Inc. 1961.

32. Kuzuya, T., E. Samols, and R.H. Wuldiams: Stimulation by hyperosmolarity of glucose metabolism in rat adipose tissue and diaphragm in vitro. J. biol. Chem. 240, $2277-2283$ (1965).

33. LyngsøE, J.: Determination of the insulin-like activity in serum using rat epididymal adipose tissue. Scand. J. clin. Lab. Invest. 13, 628-636 (1961).

34. - The insulin-like activity in serum determined by the rat epididymal fat method. IV. Anti-insulin inhibition of insulin-like activity in electrophoretically separated protein fractions. Acta med. scand. 174, $589-594(1963)$.

35. - The state of insulin in plasma. Current trends in diabetes mellitus. Acta med. scand., suppl. 476, 4352 (1967).

36. MAYER, U.A.: Stoffwechsel des Fettgewebes normaler, alloxandiabetischer und nach Nahrungskarenz wiedergefütterter Ratten während langfristiger Incubation in vitro. Diabetologia 2, 189-194 (1966).

37. Molonex, P.J.: Endogenous and pancreatic insulins. In: The Ciba Foundation Colloq. on Endocrino$\log 14,169-181$ (1962).

38. Partamian, J., E. Rasto, and G.F. Cahill : Studies using the intraperitoneal assay on the state of insulin in rat serum. Metabolism 15, 70-- 75 (1966).

39. Powrer, L., G.C. de L'Hortet, and J. Conn: The effect of frozen storage on serum insulin-like activity. Metabolism 15, 103-106 (1966). 
40. - C. LuCAs, and J.W. CoNs : Release of insulin-like activity from serum of normal subjects and diabetic patients. Metabolism 14, 110-114 (1965).

41. - - - Further studies on insulin augmentation capacities of various serum proteins. Metabolism 14, $845-849(1965)$.

42. - - - Some characteristics of the insulin augmentation phenomenon. Metabolism 14, 945-949 (1965).

43. - - - Augmentation of insulin activity. Physiological implications of a property of human serum revelated by dilution. Diabetes 14, 10-13 (1965).

44. Rasio, E.A., J.S. SOELDNER, and G.F. CAHILL: Insulin and insulin-like activity in serum and extravascular fluid. Diabetologia 1, 125-127 (1965).

45. RodBELL, M.: Metabolism of isolated fat cells. I. Effects of hormones on glucose metabolism and lipolysis. J. biol. Chem. 239, 375-380 (1964).

46. Ruedi, B., J.P. Frlber, A. Ersold, and A. VANotTr: Insuline et activité insulino-semblable. Schweiz. med. Wschr. 93, 1001-1007 (1963).

47. Samaan, N.J., J. Brown, R. Fraskr, and J. TrayNER: Effect of obesity and starvation on insulin activity. Brit. med. J. 1965 I, $1153-1156$.

48. - , and R. FRASER: Effect of circulating antibodies to insulin on serum levels of insulin-like activity in rats, guinea pigs and a diabetic patient. Brit. med. J. 1964 II, $482-485$.

49. - - , and W.J. Dempster: The "typical" and "atypical" forms of serum insulin. Diabetes 12, 339348 (1963).

50. Samaan, N.A., W.J. Demipster, R. Fraser, and D. Strllman: Changes in levels of "atypical" cireu. lating insulin after infusion of "typical" insulin through the liver. J. Endocr. 26, 1-10 (1963).

51. SAMols, E., and J.A. RYDER: Studies on tissue uptake of insulin in man using a differential immunoassay for endogenous and exogenous insulin. J. clin. Invest. 40, 2092-2102 (1961).
52. Schoeffling, K., H. Dimschunett, R. Petzoldt, J. Beyer, E.P. Pfeiffer, A. Strek, H. GeErimng, and O.V. SIREK: Serum insulin-like activity in hypophysectomized and pancreatized (Houssay) dogs. Diabetes 14, 658-662 (1965).

53. SHAW, W.N., and E.W. Shuty: The presence of two forms of insulin in normal human serum. Biochemistry 2, 286-289 (1963).

54. Sheps, M.G., R.J. NiCkerson, Y.M. Dagenats, J. Stetnke, D.B. Martin, and A.E. Revold: Measurement of small quantities of insulin-like activity using rat adipose tissue. II. Evaluation of performance. J. clin. Invest. 39, 1499-1510 (1960).

55. Siess, E., A. Teinzer, E. Struck, and O. Wietand: Bildung eines insulinartigen Wirizstoffes durch die isolierte Rattenleber. Diabetologia 1, 21-27 (1965).

56. Slater, J.D.H., N.A. Samaan, R. Fraser, and D. Stillman: Immunological studies with circulating insulin. Brit. med. J. 1961 I, $1712-1715$.

57. Sternke, J., E. Mrki, and G.F. Carrtu: Assay of crystalline insulin and of serum insulin-like activity of different species on adipose tissue of the rat, mouse and guinea pig. New Engl. J. Med. 273, 1464-1467 (1965).

58. - A. Sirek, V. Lauris, F.D.W. Lukans, and A.E. RENOLD : Measurement of small quantities of insulinlike activity with rat adipose tissue. III. Persistence of serum insulin-like activity after pancreatectomy. J. clin. Invest. 41, 1699-1707 (1962).

59. YounG, F.G.: Insulin activity in circulating blood plasma. In: Wirrians and Austis: Cell mechanisms in hormone production and action, p. 101-108 (1961).

Dr. JøRGEN GLIEMANN

Institute of Medical Physiology A

Juliane Mariesvej 28

Copenhagen $\varnothing$, Denmark 